\title{
Influence of temperature and food availability on the ecological energetics of the giant scallop Placopecten magellanicus. II. Reproductive output and total production
}

\author{
B. A. MacDonald* \& R. J. Thompson
}

Marine Sciences Research Laboratory, Memorial University of Newfoundland, St. John's, Newfoundland A1C 5S7, Canada

\begin{abstract}
Greater somatic and gonad production were generally observed in scallops Placopecten magellanicus (Gmelin) from shallow water than in those from deeper water, where temperature and food conditions were often less favourable. Annual variation in total production was attributable to differences in reproductive output rather than somatic growth, since the latter changed little from year to year. Controlled growth with opportunistic reproduction may be an appropriate strategy in the variable and unpredictable environment which scallops experience in Newfoundland
\end{abstract}

\section{INTRODUCTION}

Estimates of production have been useful in assessing the contributions of several species of marine bivalves to energy flow through the ecosystem (Rodhouse 1979, Griffiths 1981a, b, Vahl 1981) in addition to determining the suitability of different habitats to the producer (Bayne \& Worrall 1980). Many authors have attributed differences in production to temperature conditions, but recent studies have emphasized the importance of food availability and the need to measure this factor (for review see Bayne \& Newell 1983).

Total production consists of somatic tissue growth and gamete output, but the reproductive component has generally received less attention and is often omitted from production estimates (for review see Warwick 1980). Omission of the reproductive component may result in underestimation of production and turnover ratios for bivalves by as much as 80 to $90 \%$, depending on the species (Bayne \& Worrall 1980, Griffiths 1981b, Thompson 1984).

Because differences in reproductive output by some bivalves have been demonstrated within populations between various years, additional insight may be

\footnotetext{
- Present address: Department of Fisheries and Oceans, Pacific Biological Station, Nanaimo, B.C. V9R 5K6, Canada
}

gained by studying given populations for 2 or more consecutive years (Thompson 1979, Griffiths 1981b, Kautsky 1982, Bayne et al. 1983). Accurate comparisons of production estimates between populations are difficult because of spatial and temporal differences in population structure (Griffiths 1981b), and the variability of such estimates is often not quantified (Broom 1983). In the preceding paper (MacDonald \& Thompson 1985) we described differences in shell growth and somatic growth between populations of the giant scallop Placopecten magellanicus from various depths at different locations, and we showed that these differences were associated with variation in temperature and food conditions. Here we consider the production of gametes and somatic tissue in 3 consecutive years by these populations. Gametogenic cycles, scope for growth and the partitioning of energy between growth and reproduction will be considered elsewhere.

\section{MATERIALS AND METHODS}

Sampling schedules, locations of the various populations of Placopecten magellanicus and seasonal conditions of temperature and food availability were described in the preceding paper (MacDonald \& Thompson 1985). Estimates of mean somatic weights and shell heights for each age class were provided by 
polynomial regression and Von Bertalanffy equations respectively (MacDonald \& Thompson 1985). Increments in dry tissue weight (including the spent gonad), $W$, between consecutive year classes $\left(W_{(x+1)}-W_{x}\right)$ were used to estimate annual production of somatic tissue $(\mathrm{Pg})$ where $1 \mathrm{~g}$ dry weight $=24.5 \mathrm{~kJ}$ (Thompson 1977).

Gonad and somatic tissue were removed and weighed separately after drying at $90^{\circ} \mathrm{C}$. Values for gonad weights and shell heights were fitted to the allometric equation $\mathrm{y}=a \mathrm{x}^{\mathrm{b}}$ where $\mathrm{y}=$ predicted gonad weight, $\mathrm{x}=$ shell height, and $\mathrm{a}$ and $\mathrm{b}=$ fitted parameters. Since Placopecten magellanicus spawns only once a year, age-specific gamete production was estimated from the weight loss of the gonad on spawning, determined from the logarithmic regressions, where $1 \mathrm{~g}$ dry weight of eggs $=26.0 \mathrm{~kJ}$ (calculated from carbohydrate, lipid and protein content).

The follicles in the gonads of Placopecten magellanicus retain their structure after spawning (own histological obs.), unlike those of other bivalves such as Mytilus edulis (Lowe et al. 1982), and for this reason the annual increment in dry weight of the spent gonad was considered as somatic growth and included in the estimate of Pg. The organic component of the shell was not taken into account because it forms only $1.3 \%$ of the shell weight and usually represents less than $5 \%$ of the annual production of the scallops.

Statistical procedures, particularly the Bonferroni approximation, have been described previously (MacDonald \& Thompson 1985).

\section{RESULTS}

Since there were no significant differences between years in the somatic weight versus age relations for scallops from identical depths at any given location (MacDonald \& Thompson 1985), an overall mean somatic weight for each age class was estimated for each population from polynomial equations fitted to data pooled from all years. In the case of St. Andrews, where data were obtained for 1 yr only, there was no difference between depths in somatic weight at any given age, and observations from all depths were therefore pooled. As a result, somatic production $(\mathrm{Pg})$ values were identical for a particular depth at each location (or between depths in St. Andrews), and any annual differences in total production were attributable to variable gamete production (Pr) values.

There were no consistent differences between males and females in somatic weight or in gonad weight (before spawning) per unit shell length, so data for males and females were combined for the estimation of both components of total production ( $\mathrm{Pg}$ and $\mathrm{Pr}$ ).

\section{Annual variation}

The gonad weight versus shell height regressions (Table 1) were compared for each depth and site to determine if these relations varied from year to year (Table 2). Where no difference between years was demonstrated for a particular depth and location, com-

Table 1. Placopecten magellanicus. Summary of regression parameters and statistics for the relation between the weight of the ripe gonad $y(g)$ and shell height $x(m m),(\log y=\log a+b \log x)$ for all sites and depths calculated separately for each year sampled. $\cdot \mathrm{P}<0.05 ; \cdots \mathrm{P}<0.01 ; \cdots \mathrm{P}<0.001$

\begin{tabular}{|c|c|c|c|c|c|c|c|c|c|c|c|c|c|c|}
\hline & \multicolumn{3}{|c|}{ Sunnyside } & \multicolumn{3}{|c|}{ Dildo } & \multicolumn{3}{|c|}{ TNNP } & \multicolumn{3}{|c|}{ St. Andrews } & \multicolumn{2}{|c|}{ Colinet } \\
\hline & $10 \mathrm{~m}$ & $20 \mathrm{~m}$ & $31 \mathrm{~m}$ & $10 \mathrm{~m}$ & $20 \mathrm{~m}$ & $31 \mathrm{~m}$ & $10 \mathrm{~m}$ & $20 \mathrm{~m}$ & $31 \mathrm{~m}$ & $10 \mathrm{~m}$ & $31 \mathrm{~m}$ & $76 \mathrm{~m}$ & $6 \mathrm{~m}$ & $16 \mathrm{~m}$ \\
\hline \multicolumn{15}{|c|}{1981} \\
\hline $\log a$ & -5.55 & -6.93 & -4.41 & -6.11 & -3.65 & -6.37 & - & - & - & - & - & - & -7.13 & -2.99 \\
\hline $\mathrm{b}$ & 2.90 & 3.56 & 2.26 & 3.09 & 1.87 & 3.10 & - & - & - & - & - & - & 3.44 & 1.57 \\
\hline $\mathrm{n}$ & 44 & 42 & 39 & 19 & 22 & 24 & - & - & - & - & - & - & 45 & 44 \\
\hline$I^{2}$ & 0.73 & 0.77 & 0.23 & 0.75 & 0.23 & 0.87 & - & - & - & - & - & - & 0.82 & 0.17 \\
\hline$F$ & $116^{\cdots}$ & $134^{\cdots}$ & $10.8^{\cdots}$ & $52 \cdots$ & $5.8^{\circ}$ & $151^{\cdots}$ & - & - & - & - & - & - & $203 \cdots$ & $8.6^{\circ}$ \\
\hline \multicolumn{15}{|l|}{1982} \\
\hline $\log a$ & -7.59 & -7.41 & -6.16 & -3.70 & -7.06 & -7.58 & -2.08 & -6.00 & -9.31 & - & - & - & -7.60 & -4.78 \\
\hline $\mathrm{b}$ & 3.97 & 3.86 & 3.11 & 2.17 & 3.68 & 3.85 & 1.29 & 3.05 & 4.67 & - & - & - & 3.68 & 2.40 \\
\hline$n$ & 37 & 41 & 36 & 11 & 43 & 17 & 48 & 54 & 34 & - & - & - & 33 & 27 \\
\hline$r^{2}$ & 0.87 & 0.80 & 0.79 & 0.78 & 0.79 & 0.76 & 0.13 & 0.69 & 0.90 & - & - & - & 0.74 & 0.27 \\
\hline $\mathrm{F}$ & $235 \cdots$ & $155^{\cdots} \cdot$ & $128 \cdots$ & $32 \cdots$ & $154 \cdots$ & $48^{\cdots} \cdot$ & $7.1^{\circ}$ & $115 \cdots$ & $285^{\cdots} \cdots$ & - & - & - & $87^{\cdots}$ & $9.2 \%$ \\
\hline \multicolumn{15}{|c|}{1983} \\
\hline $\log a$ & -6.29 & -5.08 & -5.75 & -4.90 & -3.60 & -7.91 & -5.16 & -4.74 & -2.48 & -9.96 & -8.21 & -9.58 & -6.69 & -7.29 \\
\hline$b$ & 3.29 & 2.72 & 2.87 & 2.60 & 1.99 & 4.07 & 2.70 & 2.47 & 1.35 & 5.05 & 4.16 & 4.93 & 3.34 & 3.55 \\
\hline $\mathrm{n}$ & 41 & 32 & 48 & 29 & 32 & 31 & 31 & 29 & 34 & 43 & 41 & 18 & 36 & 37 \\
\hline $\mathrm{r}^{2}$ & 0.83 & 0.74 & 0.60 & 0.78 & 0.60 & 0.89 & 0.29 & 0.39 & 0.26 & 0.92 & 0.93 & 0.98 & 0.81 & 0.74 \\
\hline $\mathrm{F}$ & $187^{\cdots}$ & $83 \cdots$ & $69 \cdots$ & $98 \cdots$ & $45 \cdots$ & $240^{\prime} \cdot$ & $12.5^{\circ}$ & $17.0^{\circ}$ & $11.1^{\cdots}$ & $477^{\cdots}$ & $513^{\cdots}$ & $668^{\cdots}$ & $145^{\cdots}$ & $101 \cdots$ \\
\hline
\end{tabular}


Table 2. Placopecten magellanicus. Summary of $\mathrm{t}$ values for comparisons of relations between weight of ripe gonad and shell height for samples collected from identical water depths and sites but in different years. ${ }^{P}<0.05 ; \cdots P<0.01 ; \cdots P<0.001$. Note that for this table $6 \mathrm{~m}$ and $16 \mathrm{~m}$ at Colinet were considered equivalent to $10 \mathrm{~m}$ and $20 \mathrm{~m}$ elsewhere

\begin{tabular}{|c|c|c|c|c|c|c|c|c|c|c|c|}
\hline \multirow[b]{2}{*}{ Depth } & \multicolumn{4}{|c|}{1981 vs 1982} & \multicolumn{4}{|c|}{1982 vs 1983} & \multicolumn{3}{|c|}{1981 vs 1983} \\
\hline & & Sunnyside & Dildo & Colinet & Sunnyside & Dildo & Colinet & TNNP & Sunnyside & Dildo & Colinet \\
\hline $10 \mathrm{~m}$ & $\begin{array}{l}a \\
b\end{array}$ & ${ }_{3.15} \cdots$ & $\begin{array}{l}7.24 \cdots \\
1.65\end{array}$ & $\begin{array}{l}0.41 \\
0.55\end{array}$ & $\begin{array}{l}2.43^{\circ} \\
1.74\end{array}$ & $\begin{array}{l}6.76 \cdots \\
0.82\end{array}$ & $\begin{array}{l}3.24 \cdots \\
0.78\end{array}$ & $\begin{array}{l}1.34 \\
1.64\end{array}$ & $\begin{array}{l}2.06 \\
1.00\end{array}$ & $\begin{array}{l}3.45^{\circ} \cdot \\
1.05\end{array}$ & $\begin{array}{l}4.31 \cdots \\
0.26\end{array}$ \\
\hline $20 \mathrm{~m}$ & $\begin{array}{l}a \\
b\end{array}$ & $\begin{array}{l}2.51^{\circ} \\
0.73\end{array}$ & $\begin{array}{c}12.78^{\cdots} \\
0.76\end{array}$ & $\begin{array}{l}0.43 \\
0.91\end{array}$ & $\begin{array}{l}0.94 \\
2.28\end{array}$ & ${ }_{3.91} \cdots$ & $\begin{array}{l}0.77 \\
1.65\end{array}$ & $\begin{array}{l}0.87 \\
0.79\end{array}$ & $\begin{array}{l}1.50 \\
1.59\end{array}$ & $\begin{array}{l}8.48^{\cdots} \cdots \\
0.12\end{array}$ & $\begin{array}{l}0.94 \\
1.73\end{array}$ \\
\hline $31 \mathrm{~m}$ & $\begin{array}{l}a \\
b\end{array}$ & $\begin{array}{l}0.87 \\
0.98\end{array}$ & $\begin{array}{l}7.87^{\circ} \cdot \\
1.38\end{array}$ & - & $\begin{array}{l}1.20 \\
0.48\end{array}$ & $\begin{array}{l}2.87^{\circ} \\
0.41\end{array}$ & $\begin{array}{l}- \\
-\end{array}$ & $\begin{array}{c}- \\
5.82\end{array}$ & $\begin{array}{l}0.60 \\
0.75\end{array}$ & - & $\begin{array}{l}- \\
-\end{array}$ \\
\hline
\end{tabular}

mon regressions were then calculated to estimate gonad weight loss on spawning. Variable gonad weights for scallops collected from $10 \mathrm{~m}$ and $20 \mathrm{~m}$ in Sunnyside (Table 2) resulted in higher values for Pr and total production in 1982 than in 1981 and 1983 (Fig. 1, Table 3). Annual variation in gonad weight was not observed in the Sunnyside $(31 \mathrm{~m})$, Colinet $(16 \mathrm{~m})$ or Terra Nova National Park (TNNP; $10 \mathrm{~m}$, $20 \mathrm{~m}$ ) samples (Table 2), resulting in common values for Pr and total production, but year to year variation in Pr and ( $\mathrm{Pg}+\mathrm{Pr})$ was observed for all depths in Dildo and in $31 \mathrm{~m}$ at TNNP (Fig. 1 to 4 , Table $3 \& 4$ ). The 1981 and 1982 samples from $6 \mathrm{~m}$ at Colinet were similar to one another but significantly different from that of 1983.

With the exception of Dildo ( $31 \mathrm{~m})$ and Colinet $(6 \mathrm{~m})$, where Pr was greater in 1983 than 1982, the Pr values for 1982 were at least as great as those from other years at all sites (Fig. 1 to 4 ). In those sites sampled over a period of $3 \mathrm{yr}$, either very high values of $P r$ were obtained for 1982 and lower but similar Pr values for 1981 and 1983, as in the Dildo (10 m) example, or no significant differences at all were found between 1981 and 1983, e.g. at Sunnyside (10 m, $20 \mathrm{~m})$. Large annual variation was characteristic of the shallowest depths from the more productive sites, such as Sunnyside and Dildo, in contrast to less productive sites such as TNNP and Colinet.

The general trend for Pr was to increase steadily with age until an asymptote was reached (Fig. 1 to 4 ). $P g$ values increased rapidly during the first few years and, after reaching a peak at age approximately 4 or
Fig. 1 Placopecten magellanicus. Age specific somatic $(\mathrm{Pg})$ and gamete production ( $\mathrm{P}_{\mathrm{T}}$ ) in Sunnyside scallops. Pg values are for 1981, 1982 and 1983 data combined




Table 3. Placopecten magellanicus. Annual total production values, $\mathrm{Pg}+\operatorname{Pr}\left(\mathrm{kJ} \mathrm{yr}^{-1}\right)$, for each depth sampled at Sunnyside, TNNP and St. Andrews during 1981, 1982 and 1983

\begin{tabular}{|c|c|c|c|c|c|c|c|c|c|c|c|c|}
\hline \multirow[t]{3}{*}{ Age (Yr } & \multicolumn{5}{|c|}{ Sunnyside } & \multicolumn{4}{|c|}{ TNNP } & \multicolumn{3}{|c|}{ St. Andrews } \\
\hline & \multicolumn{2}{|c|}{$10 \mathrm{~m}$} & \multicolumn{2}{|c|}{$20 \mathrm{~m}$} & \multirow{2}{*}{$\begin{array}{c}31 \mathrm{~m} \\
1981 / 82 / 83\end{array}$} & \multirow{2}{*}{$\begin{array}{c}10 \mathrm{~m} \\
1982 / 83\end{array}$} & \multirow{2}{*}{$\begin{array}{c}20 \mathrm{~m} \\
1982 / 83\end{array}$} & \multicolumn{2}{|c|}{$31 \mathrm{~m}$} & \multirow{2}{*}{$\begin{array}{l}10 \mathrm{~m} \\
1983\end{array}$} & \multirow{2}{*}{$\begin{array}{l}31 \mathrm{~m} \\
1983\end{array}$} & \multirow{2}{*}{$\begin{array}{l}76 \mathrm{~m} \\
1983\end{array}$} \\
\hline & $1981 / 83$ & 1982 & $1981 / 83$ & 1982 & & & & 1982 & 1983 & & & \\
\hline 3 & 50 & 47 & 36 & 34 & 35 & - & - & - & - & 55 & 57 & 57 \\
\hline 4 & 93 & 92 & 83 & 82 & 38 & - & - & - & - & 82 & 82 & 89 \\
\hline 5 & 124 & 132 & 106 & 109 & 61 & - & 76 & - & - & 98 & 95 & 112 \\
\hline 6 & 139 & 161 & 123 & 133 & 66 & 130 & 82 & 50 & 66 & 124 & 112 & 147 \\
\hline 7 & 153 & 194 & 140 & 159 & 70 & 140 & 87 & 59 & 70 & 155 & 130 & 188 \\
\hline 8 & 166 & 229 & 155 & 186 & 74 & 144 & 92 & 68 & 70 & 190 & 151 & 235 \\
\hline 9 & 178 & 265 & 168 & 209 & 76 & 147 & 95 & 76 & 69 & 226 & 170 & 283 \\
\hline 10 & 187 & 298 & 180 & 231 & 78 & 147 & 97 & 84 & 69 & 262 & 188 & 329 \\
\hline 11 & 194 & 327 & 188 & 249 & 80 & 147 & 98 & 92 & 69 & 296 & 205 & 374 \\
\hline 12 & 198 & 353 & 193 & 263 & 80 & 145 & 98 & 99 & 68 & - & - & - \\
\hline 13 & 201 & 375 & 196 & 275 & 78 & 143 & 97 & 105 & 67 & - & - & - \\
\hline 14 & 202 & 392 & 197 & 282 & 77 & 139 & 96 & 110 & 65 & - & - & - \\
\hline 15 & 200 & 406 & 195 & 287 & 74 & 135 & 94 & 115 & 64 & - & - & - \\
\hline 16 & 197 & 416 & 191 & 288 & 71 & 131 & 92 & 119 & 62 & - & - & - \\
\hline 17 & 192 & 423 & 185 & 287 & 65 & 125 & 89 & 122 & 61 & - & - & - \\
\hline 18 & 184 & 425 & 178 & 283 & 61 & 121 & 86 & 125 & 59 & - & - & - \\
\hline 19 & 176 & 426 & 168 & 277 & 55 & 115 & 83 & 127 & 57 & - & - & - \\
\hline
\end{tabular}
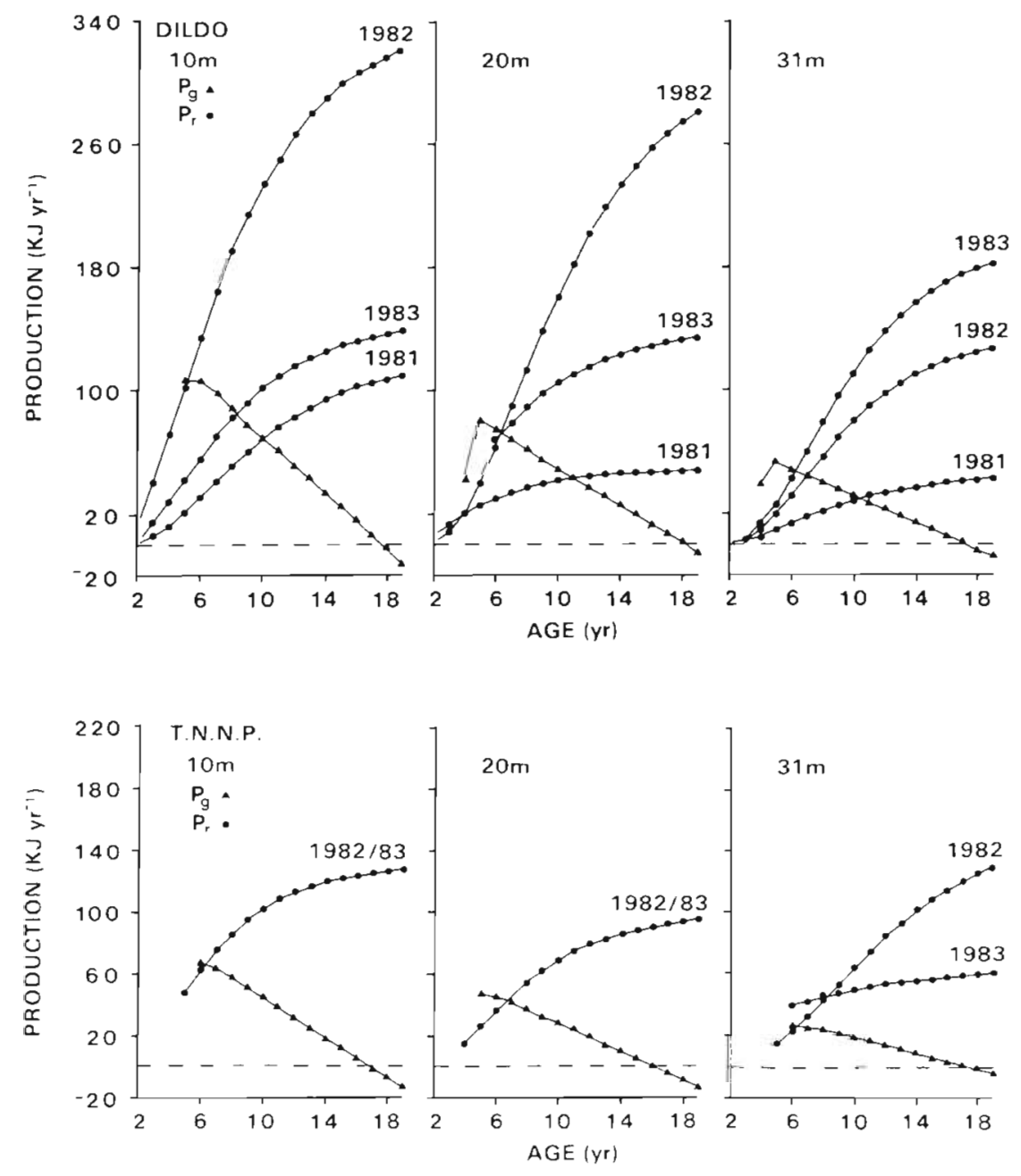

Fig. 2. Placopecten magellanicus. Age specific somatic $(\mathrm{Pg})$ and gamete production (Pr) in Dildo scallops. Pg values are for 1981, 1982 and 1983 data combined
Fig. 3. Placopecten magellanicus. Age specific somatic $(\mathrm{Pg})$ and gamete production (Pr) in TNNP scallops. Pg values are for 1982 and 1983 data combined 
Fig. 4. Placopecten magellanicus. Age specific somatic $(\mathrm{Pg})$ and gamete production $(\mathrm{Pr})$ in $\mathrm{St}$. Andrews and Colinet scallops. Pg values are for 1981, 1982 and 1983 data combined (Colinet) and for 10, 31, and $76 \mathrm{~m}$ combined (St. Andrews)

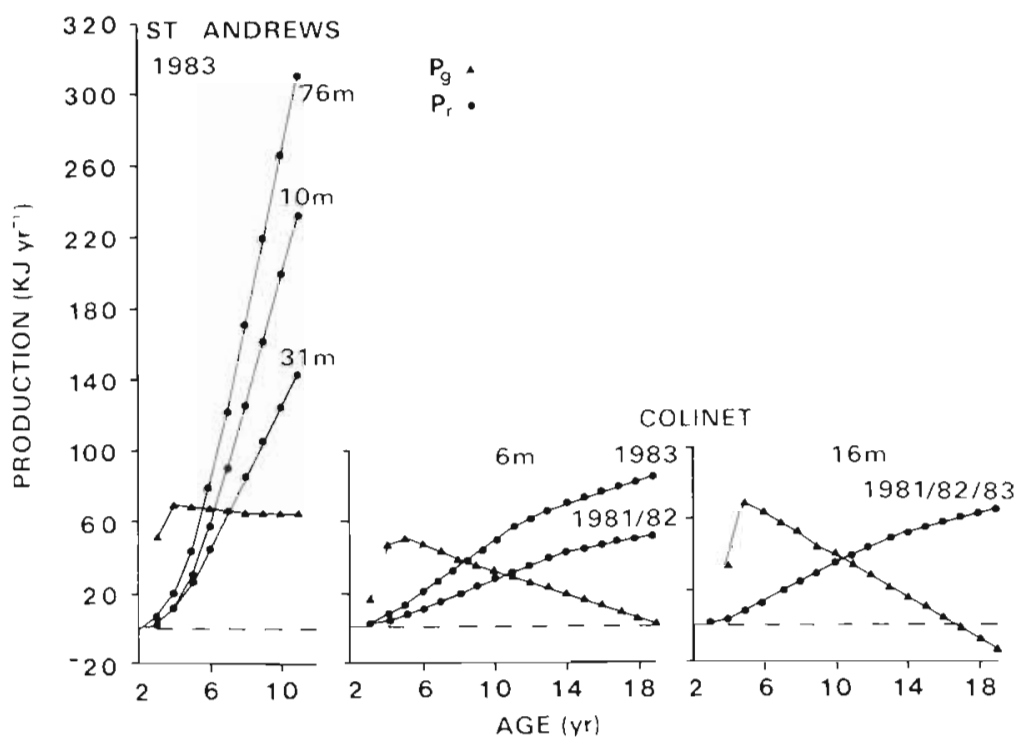

$5 \mathrm{yr}$, they steadily declined with age until 17 or $18 \mathrm{yr}$, when they become negative, owing to the decrease in somatic weight which occurs in older scallops (MacDonald \& Thompson 1985).

Total production $(\mathrm{Pg}+\mathrm{Pr})$ increased with age during the earliest years, but after $(\mathrm{Pg}+\mathrm{Pr})$ reached a maximum, a gradual decline in subsequent years was demonstrated in almost all the long-lived Newfoundland populations (Tables $3 \& 4$ ). Decreasing total production was a result of $\mathrm{Pg}$ declining faster than Pr was increasing. Exceptions included the Sunnyside $10 \mathrm{~m}$ and $20 \mathrm{~m}$ samples collected in 1982, in which Pr was increasing at a faster rate than Pg was declining, and the St. Andrews populations.

\section{Differences related to water depth}

In scallops from Sunnyside, Dildo and TNNP, there was a negative correlation between age-specific $\mathrm{Pg}$ and depth (Fig. 1 to 3), whereas at Colinet and St. Andrews there was no such variation in somatic production (Fig. 4).

In each year at Sunnyside, slopes for the regressions

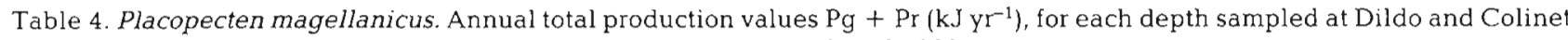
during 1981, 1982 and 1983

\begin{tabular}{|c|c|c|c|c|c|c|c|c|c|c|c|c|}
\hline \multirow[t]{2}{*}{ Age (yr) } & \multicolumn{9}{|c|}{ Dildo } & \multicolumn{3}{|c|}{ Colinet } \\
\hline & 1981 & $\begin{array}{l}10 \mathrm{~m} \\
1982\end{array}$ & 1983 & 1981 & $\begin{array}{l}20 \mathrm{~m} \\
1982\end{array}$ & 1983 & 1981 & $\begin{array}{l}31 \mathrm{~m} \\
1982\end{array}$ & 1983 & $\begin{array}{c}6 \mathrm{~m} \\
1981 / 82\end{array}$ & $\begin{array}{c}6 \mathrm{~m} \\
1983\end{array}$ & $\begin{array}{c}16 \mathrm{~m} \\
1981-83\end{array}$ \\
\hline 3 & - & - & - & - & - & - & - & - & - & 16 & 18 & - \\
\hline 4 & - & _. & - & 62 & 65 & _ & 44 & 49 & 52 & 37 & 52 & 37 \\
\hline 5 & 128 & 212 & 150 & 106 & 122 & - & 63 & 74 & 79 & 67 & 62 & 76 \\
\hline 6 & 138 & 245 & 164 & 104 & 138 & - & 63 & 81 & 92 & 56 & 65 & 75 \\
\hline 7 & 139 & 263 & 168 & 102 & 157 & 142 & 62 & 88 & 105 & 57 & 69 & 75 \\
\hline 8 & 139 & 280 & 171 & 99 & 175 & 151 & 62 & 97 & 119 & 57 & 72 & 75 \\
\hline 9 & 139 & 294 & 172 & 95 & 193 & 153 & 61 & 104 & 132 & 58 & 77 & 74 \\
\hline 10 & 139 & 306 & 172 & 91 & 210 & 154 & 60 & 110 & 143 & 58 & 79 & 74 \\
\hline 11 & 137 & 314 & 170 & 86 & 225 & 154 & 58 & 115 & 153 & 58 & 82 & 73 \\
\hline 12 & 135 & 320 & 167 & 81 & 339 & 153 & 57 & 119 & 161 & 59 & 84 & 72 \\
\hline 13 & 132 & 324 & 164 & 77 & 250 & 151 & 54 & 122 & 167 & 58 & 85 & 70 \\
\hline 14 & 127 & 324 & 159 & 71 & 258 & 149 & 51 & 123 & 171 & 57 & 86 & 67 \\
\hline 15 & 123 & 325 & 154 & 65 & 264 & 145 & 49 & 123 & 174 & 56 & 87 & 65 \\
\hline 16 & 118 & 323 & 147 & 60 & 269 & 142 & 45 & 123 & 176 & 55 & 86 & 62 \\
\hline 17 & 112 & 320 & 141 & 54 & 273 & 138 & 42 & 122 & 176 & 53 & 86 & 57 \\
\hline 18 & 106 & 317 & 134 & 48 & 275 & 133 & 38 & 120 & 176 & 50 & 85 & 54 \\
\hline 19 & 98 & 312 & 127 & 43 & 276 & 129 & 34 & 118 & 175 & 49 & 84 & 50 \\
\hline
\end{tabular}


of gonad weight against shell height were similar for all depths (Table 5). Elevations were not significantly different between $10 \mathrm{~m}$ and $20 \mathrm{~m}$, but gonad weight was significantly lower in scallops from $31 \mathrm{~m}$ than in those from shallower water. Age-specific reproductive output was always greater in $10 \mathrm{~m}$ and $20 \mathrm{~m}$ than in $31 \mathrm{~m}$ (Fig. 1), and in 1982 there was a negative correlation between Pr and depth at Sunnyside. In 1981 and 1983, however, Pr was the same at $10 \mathrm{~m}$ and $20 \mathrm{~m}$. Total production at Sunnyside was a decreasing function of depth (Table 3).

Gonad weight was significantly lower in scallops from $31 \mathrm{~m}$ at Dildo in 1981 than in scallops from $10 \mathrm{~m}$, but the $20 \mathrm{~m}$ samples were similar to those from $10 \mathrm{~m}$ and $31 \mathrm{~m}$ (Table 5). In 1982, however, the 2 shallow populations $(10 \mathrm{~m}, 20 \mathrm{~m})$ displayed different regression slopes from one another, but both differed in slope and elevation from the $31 \mathrm{~m}$ sample, resulting in greater gonad weights for the 2 shallow samples. Regressions for scallops from $10 \mathrm{~m}$ and $20 \mathrm{~m}$ in 1983 had equal slopes and elevations, but the slope for the $31 \mathrm{~m}$ sample was different. With the exception of a very productive sample from $31 \mathrm{~m}$ in 1983, a general trend of similarities between $10 \mathrm{~m}$ and $20 \mathrm{~m}$ samples but declining $\mathrm{Pr}$ and $(\mathrm{Pg}+\mathrm{Pr})$ values with increasing depth was also apparent in the Dildo data (Fig. 2, Table 4).

There were no differences in the gonad weight versus shell height relations for scallops from different depths at TNNP in 1983, but they all differed in slope in 1982 (Table 5). With the exception of the 1982 sample from $31 \mathrm{~m}$, TNNP scallops showed a decrease in $\mathrm{Pr}$ and $(\mathrm{Pg}+\mathrm{Pr})$ with increasing depth (Fig. 3, Table 3).

The gonad weight versus shell height regressions for scallop samples from $6 \mathrm{~m}$ and $16 \mathrm{~m}$ at Colinet had different slopes in 1981, similar slopes but different elevations in 1983 and were equal in 1982 (Table 5). Greater values of $(\mathrm{Pg}+\mathrm{Pr})$ were obtained in scallops from $16 \mathrm{~m}$ except in 1983, although differences in agespecific Pr and total production between depths at Colinet were very small (Fig. 4, Table 4).

At St. Andrews, only the gonad weight versus shell height regressions for the $10 \mathrm{~m}$ and $31 \mathrm{~m}$ samples were significantly different in 1983 (Table 5). There were between-depth differences in age-specific Pr and total production at St. Andrews, the greatest values occurring in the deepest water i.e. $76 \mathrm{~m}>10 \mathrm{~m}>31 \mathrm{~m}$ (Fig. 4, Table 3).

The turnover ratios (or production/biomass ratios) were calculated for each age class using the term $(\mathrm{Pg}+\mathrm{Pr}) / \overline{\mathrm{B}}$ where $\overline{\mathrm{B}}$ is the mean somatic weight. Mean $\mathrm{P} / \overline{\mathrm{B}}$ ratios for all 3 depths in each year were obtained by pooling data from Sunnyside, Dildo and TNNP populations (Fig. 5). The ratios rapidly declined during the first $10 \mathrm{yr}$, but changed very little thereafter.

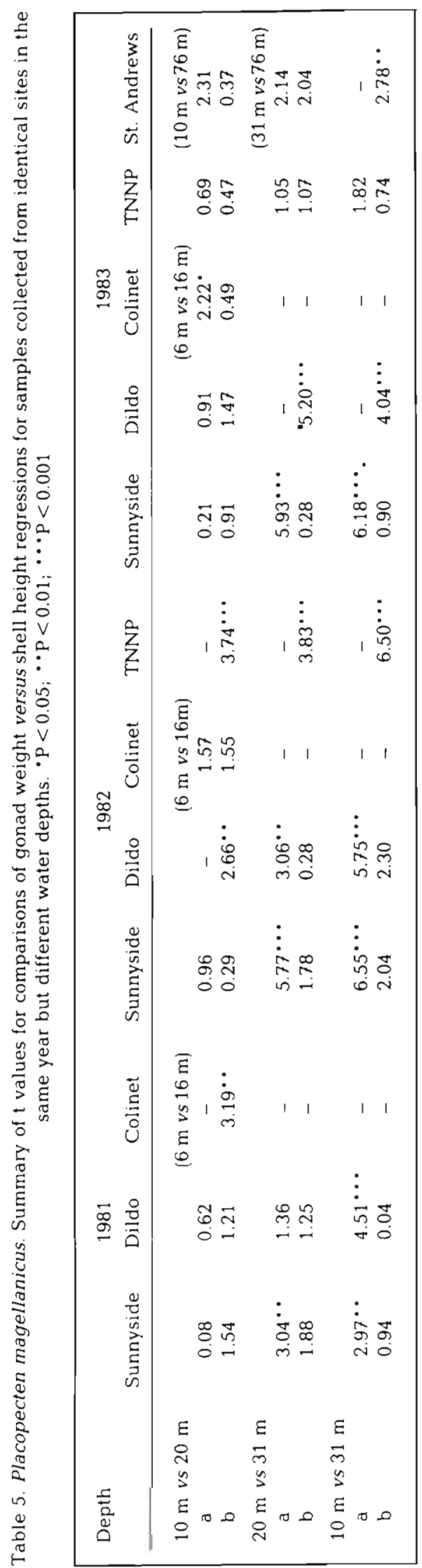


Fig. 5. Placopecten magellanicus. Mean turnover ratios for pooled Sunnyside, Dildo and TNNP data. $\bar{B}$ : mean somatic weight of an individual scallop


Despite the much greater somatic weights of scallops from shallow water, these animals were generally more productive per unit weight than those from deeper water, except in 1983 when a very productive (i.e. high Pr and low biomass) $31 \mathrm{~m}$ sample from Dildo may have strongly influenced the mean. There was some annual variation in the turnover ratio in scallops from $10 \mathrm{~m}(1982>1983>1981)$ and in those from $31 \mathrm{~m}$ (1982, $1983>1981)$. Our observations are consistent with those of Shafee \& Conan (1984) for Chlamys varia, in which there is a decrease in the turnover ratio in older animals and also year-to-year variation in $\mathrm{P} / \overline{\mathrm{B}}$.

\section{Site related differences}

Direct comparisons of growth and reproductive output were made between Sunnyside, Dildo and TNNP samples only, because at these locations scallops were obtained from the same 3 water depths $(10 \mathrm{~m}, 20 \mathrm{~m}$ and $31 \mathrm{~m})$. The corresponding $\mathrm{Pg}$ values for each depth were slightly higher in Dildo than in Sunnyside scallops, but values for the TNNP samples were lower than those for the other 2 sites (Fig. 1 to 3 ).

The gonad weight versus shell height regressions for the Dildo and Sunnyside $20 \mathrm{~m}$ samples in 1981 were similar, but lower elevations were observed for the Dildo $10 \mathrm{~m}$ and $31 \mathrm{~m}$ samples (Table 6). Total production estimates and Pr values were lower for Dildo scallops than for scallops from comparable depths at Sunnyside in 1981 (Fig. 1 \& 2, Table 3 \& 4).
The slope of the gonad weight versus shell height regression for Sunnyside scallops from $10 \mathrm{~m}$ in 1982 was different from those for TNNP and Dildo samples, and lower weights were observed in TNNP scallops than in Dildo scallops (Table 6). At $20 \mathrm{~m}$ the gonad weight relations for Sunnyside and Dildo samples were equivalent, but both had greater elevations than TNNP samples. A.t $31 \mathrm{~m}$ the regression slopes for Sunnyside and TNNP populations were different from one another, but both were similar to Dildo samples. In 1982 greater values for $\mathrm{Pr}$ and total production were observed at $10 \mathrm{~m}$ and $20 \mathrm{~m}$ in Sunnyside than at Dildo or TNNP (Fig. 1 to 3 , Table 3 \& 4). Similar Pr values were seen in the $31 \mathrm{~m}$ scallops from all 3 sites, but total production was greater in scallops from Dildo and TNNP than in those from Sunnyside.

The gonad weight versus shell height regressions for Dildo scallops at $10 \mathrm{~m}$ in 1983 were similar to those for TNNP and Sunnyside scallops, but the Sunnyside animals had heavier gonads than those from TNNP (Table 6). At $20 \mathrm{~m}$, the Dildo and Sunnyside samples were again equivalent, but TNNP scallops had lower gonad weights than those from either of the other 2 sites. Regressions for scallops from $31 \mathrm{~m}$ at TNNP were not significantly different from those for Sunnyside samples, but differed in slope from those for Dildo scallops, which had heavier gonads than Sunnyside animals. In 1983 greater values for Pr and total production were found in the Sunnyside $10 \mathrm{~m}$ and $20 \mathrm{~m}$ samples than in Dildo or TNNP scallops from similar depths (Fig. 1 to 3, Table $3 \& 4$ ). At $31 \mathrm{~m}$ in 1983, Pr and

Table 6. Placopecten magellanicus. Summary of $\mathrm{t}$ values for comparisons of gonad weight versus shell height regressions between scallops from identical water depths and years but from different sites. ${ }^{P} \mathrm{P}<0.05 ;{ }^{*} \mathrm{P}^{\bullet}<0.01 ;{ }^{\cdots} \cdot \mathrm{P}<0.001$

\begin{tabular}{|c|c|c|c|c|c|c|c|c|c|c|c|c|c|c|}
\hline \multirow[t]{3}{*}{ Depth } & \multicolumn{6}{|c|}{ Sunnyside vs Dildo } & \multicolumn{4}{|c|}{ Dildo vs TNNP } & \multicolumn{4}{|c|}{ Sunnyside vs TNNP } \\
\hline & \multicolumn{2}{|c|}{1981} & \multicolumn{2}{|c|}{1982} & \multicolumn{2}{|c|}{1983} & \multicolumn{2}{|c|}{1982} & \multicolumn{2}{|c|}{1983} & \multicolumn{2}{|c|}{1982} & \multicolumn{2}{|c|}{1983} \\
\hline & a & $\mathrm{b}$ & a & $b$ & a & $\mathrm{b}$ & a & $\mathrm{b}$ & a & $\mathrm{b}$ & a & b & a & $b$ \\
\hline $10 \mathrm{~m}$ & $2.13^{\circ}$ & 0.31 & - & $2.66^{\circ}$ & 1.10 & 1.28 & $2.69^{\cdots}$ & 1.36 & 1.03 & 0.81 & - & $5.54 \cdots$ & $2.44^{\circ}$ & 2.02 \\
\hline $20 \mathrm{~m}$ & 1.57 & 1.30 & 0.46 & 0.39 & 0.94 & 1.53 & $4.98 \cdots$ & 1.30 & $3.10=$ & 0.75 & $6.02 \cdots$ & 2.10 & $4.27^{\cdots} \cdot$ & 0.43 \\
\hline $31 \mathrm{~m}$ & $3.19^{\circ}$ & 1.16 & 2.12 & 1.13 & $5.54 \cdots$ & 2.16 & 0.34 & 1.22 & - & $2.61^{\cdots}$ & - & $4.04^{\cdots}$ & 1.72 & 1.61 \\
\hline
\end{tabular}


$(\mathrm{Pg}+\mathrm{Pr})$ were greater in Dildo scallops than in those from Sunnyside or TNNP.

In any given year, $\mathrm{Pr}$ and $(\mathrm{Pg}+\mathrm{Pr})$ were lower in scallops from $6 \mathrm{~m}$ at Colinet than in those from $10 \mathrm{~m}$ at other sites, especially Sunnyside and Dildo. Reproductive output and total production were lower in Colinet scallops from $16 \mathrm{~m}$ than in those from $20 \mathrm{~m}$ at any other site in any given year, with the exception of 1981, when they were similar to Dildo scallops.

\section{DISCUSSION}

We have previously shown that the greater food ration and higher temperatures characteristic of very shallow water environments $(6$ to $10 \mathrm{~m})$ in eastern Newfoundland are more conducive to the growth of the shell and the somatic tissue in Placopecten magellanicus than are conditions in deeper water (MacDonald \& Thompson 1985). Here we have demonstrated that reproductive output is also greater in scallops from shallow water. Consequently, considerable differences in total production are observed between deep and shallow water populations, e.g. in 1982 at Sunnyside, where scallops from $10 \mathrm{~m}$ were almost 8 times more productive than those from $31 \mathrm{~m}$. Similar observations of enhanced reproductive output and total production under better environmental conditions have been reported by Bayne \& Worrall (1980) for populations of Mytilus edulis only a few $\mathrm{km}$ apart.

At St. Andrews, New Brunswick, where the water column is thoroughly mixed by tidal forces, there is no difference in shell growth or somatic growth between scallops from various depths, and at Colinet, Newfoundland, where the water is very shallow, scallops from $6 \mathrm{~m}$ and $16 \mathrm{~m}$ have identical shell growth rates, as well as similar rates of somatic growth and total production by individuals (MacDonald \& Thompson 1985). Nevertheless, in some instances (e.g. St. Andrews; Dildo in 1983) scallops from deep water may be more productive than those from shallow water, owing to enhanced reproductive output in the former, but we are unable to relate this to environmental conditions, since we have no measurements of food ration at these sites. Furthermore, shell growth and somatic growth are not necessarily good indicators of environmental quality, although the estimates of total production confirm our earlier conclusions (MacDonald \& Thompson 1985) that Sunnyside and Dildo are more favourable locations for scallops than TNNP or Colinet.

Reproductive output varies not only between populations from different depths or sites, but also between consecutive years in a given population. This suggests that gamete production is strongly influenced by environmental conditions, and that annual variation in total production for individual scallops from Newfoundland populations is primarily attributable to variable gamete production, since there is little variation in somatic growth from year to year (MacDonald \& Thompson 1985). Annual variation in fecundity has been recorded in Placopecten magellanicus by Thompson (1977) and in mytilids by Thompson (1979), Griffiths (1981b), Kautsky (1982) and Bayne et al. (1983). In some of our Newfoundland sites, conditions for scallop production in 1982 were more favourable than in 1981 or 1983 (MacDonald \& Thompson 1985). For example, the greater production of gametes by scallops from $10 \mathrm{~m}$ at Sunnyside in 1982 was associated with greater food availability in that year, compared with poorer ration conditions and lower productivity by scallops in 1983. Lower summer temperatures at Sunnyside before spawning in 1982 may also have contributed to an increased reproductive output by reducing the maintenance energy requirement.

Male and female scallops from given sites and depths have similar somatic growth rates and, with a few exceptions, the same reproductive output. Differences or similarities between males and females in terms of growth and production may depend on the species and the location. For example, in the mytilids Aulacomya ater and Choromytilus meridionalis there are no differences in growth and production between the sexes (Griffiths \& King 1979, Griffiths 1981b), but differences have been observed by Sprung (1983) in Mytilus edulis and by Sundet \& Lee (1984) in the Iceland scallop Chlanys islandica.

In general, greater somatic growth and reproductive output are found in scallops from shallow water or from more favourable sites, and differences in production are well correlated with food availability and temperature. It is probable, however, that there are qualitative differences in ration (e.g. fatty acids, amino acids) between depths and sites, which may contribute to variation between populations in growth and gamete production and which merit consideration in future work.

The environment that scallops experience in Newfoundland is both variable and unpredictable, and it may be an appropriate reproductive strategy to invest any surplus energy in gametes when more favourable conditions are encountered. If the additional energy were allocated to somatic growth, the scallop may not be able to support a larger body mass should environmental conditions deteriorate in subsequent years. Controlled growth with opportunistic reproduction is a more conservative strategy which may account in part for the highly variable recruitment characteristic of populations of Placopecten magellanicus in Newfoundland. 
Acknowledgements. We thank G. Chaisson, R. Guest, J. Woolridge, R. O'Donnell, J. Ennis and A. Barnes for their valuable assistance in the field, and J. Senciall for help in the laboratory. Samples of scallops from St. Andrews, and laboratory facilities there, were kindly provided by Dr R. Elner and R. Chandler (Department of Fisheries and Oceans). We acknowledge the enthusiasm and support of Parks Canada personnel, particularly Superintendent R. Orr and Warden J. Tucker at Terra Nova National Park. Considerable assistance with statistical procedures was provided by Dr. A. Cornish. We thank Dr. B. L. Bayne for helpful discussions and criticism of the manuscript. The work was supported by an NSERC (Canada) operating grant to R.J.T. and by scholarships to B.A.M. from the Marine Sciences Research Laboratory and the Faculty of Graduate Studies, Memorial University of Newfoundland. Marine Sciences Research Laboratory Contribution No. 597

\section{LITERATURE CITED}

Bayne, B. L., Newell, R. C. (1983). Physiological energetics of marine molluscs. In: Saleuddin, A. S. M., Wilbur, K. M. (ed.) The Mollusca. Vol. 4 (1). Academic Press, New York, p. $407-415$

Bayne, B. L., Salkeld, P. N., Worrall, C. M. (1983). Reproductive effort and value in different populations of the marine mussel Mytilus edulis L. Oecologia (Berl.) 59: 18-26

Bayne, B. L., Worrall, C. M. (1980). Growth and production of mussels Mytilus edulis from two populations. Mar. Ecol Prog. Ser. 3: 317-328

Broom, M. J. (1983). Mortality and production in naturaI artificially seeded and experimental populations of Anadara granosa (Bivalvia: Arcidae). Oecologia (Berl.) 58: 389-397

Griffiths, C. L., King, J. A. (1979). Energy expended on growth and gonad output in the ribbed mussel Aulacomya ater. Mar. Biol. 53: 217-222

Griffiths, R. J. (1981a). Population dynamics and growth of the bivalve Choromytilus meridionalis (Kr.) at different tidal levels. Estuar coast. Shelf Sci. 12: 101-118

Griffiths, R. J. (1981b). Production and energy flow in relation to age and shore level in the bivalve Choromytilus meridionalis (Kr.). Estuar. coast. Shelf Sci. 13: 477-493
Kautsky, N. (1982). Quantitative studies on gonad cycle, fecundity, reproductive output and recruitment in a Baltic Mytilus edulis population. Mar. Biol. 68: 143-160

Lowe, D. M., Moore, M. N., Bayne, B. L. (1982). Aspects of gametogenesis in the marine mussel, Mytilus edulis (L.). J. mar. biol. Ass. U.K. 62: 133-145

MacDonald, B. A., Thompson, R. J. (1985). Influence of temperature and food availability on the ecological energetics of the giant scallop Placopecten magellanicus. I. Growth rates of shell and somatic tissue. Mar. Ecol. Prog. Ser. 25: 279-294

Rodhouse, P. G. (1979). A note on the energy budget for an oyster population in a temperate estuary. J. exp. mar. Biol. Ecol. 37: 205-212

Shafee, M. S., Conan, G. (1984). Energetic parameters of a population of Chlamys varia (Bivalvia: Pectinidae). Mar. Ecol. Prog. Ser. 18: 253-262

Sprung, M. (1983). Reproduction and fecundity of the mussel Mytilus edulis at Helgoland (North Sea). Helgoländer Meeresunters. 36: 243-255

Sundet, J. H., Lee, J. B. (1984). Seasonal variations in gamete development in the Iceland scallop, Chlamys islandica. J. mar. biol. Ass. U.K. 64: 411-416

Thompson, R. J. (1977). Blood chemistry, biochemical composition and the annual reproductive cycle in the giant scallop, Placopecten magellanicus, from southeast Newfoundland. J. Fish. Res. Bd Can. 34: 2104-2116

Thompson, R. J. (1979). Fecundity and reproductive effort in the blue mussel (Mytilus edulis), the sea urchin (Strongylocentrotus droebachiensis) and the snow crab (Chionoecetes opilio) from populations in Nova Scotia and Newfoundland. J. Fish. Res. Bd Can. 36: 955-964

Thompson, R. J. (1984). Production, reproductive effort, reproductive value and reproductive cost in a population of the blue mussel Mytilus edulis from a subarctic environment. Mar. Ecol. Prog. Ser. 16: 249-257

Vahl, O. (1981). Energy transformations by the Iceland scallop, Chlamys islandica (O. F. Müller), from $70^{\circ} \mathrm{N}$. I. The age-specific energy budget and net growth efficiency. $\mathrm{J}$. exp. mar. Biol. Ecol. 53: 281-296

Warwick, R. M. (1980). Population dynamics and secondary production of benthos. In: Tenore, K. R., Coull, B. C. (ed.) Marine benthic dynamics. Univ. S. Carolina Press, Columbia, p. 451 